\title{
INDIVIDUAL DIFFERENCES CONCERNING THE IMPACT OF FEEDBACK - SPECIFYING THE ROLE OF CORE SELF-EVALUATIONS
}

\author{
Bjoern KRENN ${ }^{1}$, Sabine WUERTH ${ }^{2}$, Andreas HERGOVICH ${ }^{3}$ \\ ${ }^{1}$ Centre for Sports Sciences and University Sports \\ Department of Sports Sciences, University of Vienna \\ Auf der Schmelz 6a, 1150 Vienna, Austria \\ E-mail: bjoern.krenn@univie.ac.at \\ 2 Department of Sport Science \& Kinesiology, University of Salzburg \\ Schlossallee 49, 5400 Hallein-Rif, Austria \\ E-mail: sabine.wuerth@sbg.ac.at \\ ${ }^{3}$ Department of Applied Psychology: Work, Education and Economy \\ Faculty of Psychology, University of Vienna \\ Universitätsstraße 7,1010 Vienna, Austria \\ E-mail: andreas.hergovich@univie.ac.at
}

\begin{abstract}
The impact of feedback on performance turned out to be inconsistent with respect to the significance of a wide range of moderating variables. Concerning personality traits, generalized self-efficacy, self-esteem, locus of control, and emotional stability have been shown to affect the processing of feedback. So far, feedback research has observed these traits in isolation, neglecting their interrelations. This study was carried out to investigate the impact of an integrative, higher order concept including these traits (termed as core self-evaluations) on the effects of feedback interventions. Participants $(\mathrm{N}=471)$ received manipulated positive, negative or no feedback (control group) in the scope of two test performances conducted on the computer. Confirmatory factor analysis corroborated the concept of core self-evaluations. Repeated measures ANOVA did not reveal an effect of core self-evaluations on the impact of feedback. Considering the single traits, solely self-esteem turned out to affect the power of feedback.
\end{abstract}

Key words: feedback, self-efficacy, self-esteem, locus of control, neuroticism

Numerous studies have revealed the power of feedback and emphasized its impact on performance (e.g., Bangert-Drowns et al., 1991; Hattie, Timperley, 2007; Kluger, DeNisi, 1996; Mory, 2004). Feedback allows the evaluation of achieved performance and enables the comparison of target state with actual state. Thus, discrepancies between observed and desired achievement are uncovered and they influence subsequent per- formance. However, the effect of feedback on individual performance turned out to be controversial. Several studies demonstrated that positive as well as negative feedback mostly improved performance, whereas other studies reported no or even debilitating effects (cf., Hattie, Timperley, 2007; Kluger, DeNisi, 1996; Smither, London, Reilly, 2005). Shute (2008) particularly emphasized that despite the existence of a large body of feed-

DOI: $10.21909 /$ sp.2013.02.628 
back research, there are still minor consistent findings. Hence, analyzing factors which moderate the impact of feedback seems of fundamental importance.

Kluger and DeNisi (1996) demonstrated that the power of feedback is determined by its style (e.g., Lipnevich, Smith, 2009; Mory, 2004; Narciss, 2008), the characteristics of the task (e.g., Clariana et al., 2000; Hattie, Timperley, 2007; Magill, 2001), situational characteristics (e.g., Chen Idson, Higgins, 2000; Förster et al., 2001; Van-Dijk, Kluger, 2004) as well as an individual's personality. Even when several authors called for more studies examining how feedback is perceived and responded to by recipients (e.g., Kinicki et al., 2004; Kluger, DeNisi, 1996; London, Smither, 1995), research has fallen short of studies that explicitly address personality traits as moderators of feedback effects. So far, generalized self-efficacy (GSE), self-esteem (SE), locus of control (LOC), and neuroticism have been shown to affect the impact of feedback. However, most of the studies considered these traits separately, irrespective of their interrelations. Even when two or more traits were included in the same study, they were examined in isolation.

Judge, Lock and Durham (1997) demonstrated, concerning the traits of GSE, SE, LOC and neuroticism, that these concepts form a higher order personality trait, which is referred to as core self-evaluations (CSE). The authors emphasized that because of its breadth, CSE should represent a stronger predictor for any evaluation processes than a single CSE trait. In this regard, we purposed this study to analyze the overall impact of the concept of CSE on the effects of positive and negative feedback interventions.

\section{Core Self-Evaluations and Their Impact on Feedback}

The concept of core self-evaluations (CSE) was introduced by Judge et al. (1997). Judge and his colleagues (Bono, Judge, 2003; Judge et al., 1997; Judge et al., 1998) noted that GSE, SE, LOC and neuroticism form a broad personality trait, which is related to job satisfaction (examined for physicians, business school graduates and working students). In their meta-analysis of 127 studies Judge, Erez, Bono, and Thoresen (2002) reported moderate to high estimated correlations between these traits (from .40 between internal LOC and emotional stability - representing a low level of neuroticism - to .85 between GSE and SE). Considering their conceptual similarities and empirical interrelations, it was supposed that these traits build an integrative, higher order personality concept: Exploratory as well as confirmatory factor analyses revealed that the traits indicate a single factor (average loadings: GSE: .81, SE: .91, LOC: .74, emotional stability: .73) which is a strong predictor of motivation and job satisfaction (Bono, Judge, 2003; Erez, Judge, 2001). However, the model of CSE has received some criticism, which questions the interrelatedness and appropriateness of the single traits (Chang et al., 2012; Dormann et al., 2006). Especially, emotional stability and locus of control seemed to contribute less to the model of CSE (Chang et al., 2012; Johnson, Rosen, Djurdjevic, 2011; Johnson, Rosen, Levy, 2008). Thus, measuring the single traits separately and reanalyzing the structure of CSE was recommended rather than assessing CSE by a single scale measure (e.g., Core SelfEvaluation Scale, Judge et al., 2003; see also Gardner, Pierce, 2009; Stumpp et al., 2010). 
In the field of feedback research, the traits of GSE, SE and LOC particularly proved to be meaningful predictors for the impact of feedback on performance. Despite the strong empirical relations of these traits as well as the knowledge of their individual influence on feedback, studies have neglected to examine their overall impact on task performance. The personality traits were considered separately for the most part. To our knowledge, merely two studies examined the concept of CSE with regard to feedback: They revealed positive relations between CSE and satisfaction following evaluative feedback (Kamer,Annen, 2010) as well as between CSE and goal commitment following multisource feedback when individual self-rating exceeded ratings given by others (Bono, Colbert, 2005). However, the current study was designed to analyze the immediate relationship between CSE and performance following positive and negative normative feedback. The following sections will summarize the most important results, accentuating the impact of these four CSE traits on performance considering differential feedback interventions.

Self-efficacy: Self-efficacy is defined as an individual's judgment concerning his or her ability to perform in a specific situation (Bandura, 1997), whereas GSE can be understood as the belief in one's own ability to perform across a variety of situations (cf., Bono, Judge, 2003). According to the nature of feedback, Heslin and Latham (2004) demonstrated that managers with high self-efficacy benefitted more from feedback given by their subordinates. They improved their performance significantly in comparison to those with low self-efficacy scores. In general, Karl, O'Leary-Kelly, and Martocchio (1993) showed that the impact of feedback (knowledge of outcome) on performance was more pronounced for people with high selfefficacy. Positive feedback caused a stronger improvement in performance for people with high self-efficacy than for low self-efficacy individuals. Similar results were found following negative performance feedback: High self-efficacy caused more effort than low self-efficacy (cf., Podsakoff, Farh, 1989). Thus, it was expected that high self-efficacy individuals would improve their performance more following positive and negative feedback than low self-efficacy individuals (see also Bandura, Cervone, 1983).

Self-esteem: Individual SE seems highly important in determining the impact of feedback (Fedor et al., 2001; Ilgen, Fisher, Taylor, 1979). It can be defined as a global and basic evaluation with reference to the value individuals place on themselves (Baumeister et al., 2003). It was shown that the level of SE influences the response to negative and positive feedback: Subjects with high SE improved their performance more than subjects with low SE after positive feedback. In contrast, a low SE caused a stronger decline in performance subsequent to negative performance feedback than a high SE (Brockner, Derr, Laing, 1987; Shrauger, Rosenberg, 1970; see also Bernichon, Cook, Brown, 2003; Heimpel et al., 2002). In reference to this, Brown (2010) argued that a high SE lowers the individual relevance of negative feedback and therefore lowers its impact. Thus, a high level of SE improved the handling of negative feedback. Regarding the condition of positive feedback, it was argued that feedback would be more attributed to individual achievement and would therefore increase performance. In line with this theory, Di Paula and Campbell (2002) found that participants with high SE persisted more than low SE par- 
ticipants after a single failure, whereas individuals with low SE ruminated more than high SE individuals. In general, it was expected that high SE individuals would benefit more from positive and negative feedback to improve their performance.

Locus of control: In contrast to traits such as self-efficacy or SE, less is known about the role of LOC considering the impact of performance feedback. LOC represents a personality trait which stands for the individual belief that encountered events are controlled by one's individual actions or by other forces (McCarthy, Garavan, 2007). Individuals with an internal LOC (internals) believe in their ability to control events and attribute failure or success predominantly to themselves. In contrast, people with an external LOC (externals) have low expectations of control and attribute failure or success to external sources (e.g., other people, fate, fortune). According to the nature of feedback Baron and Ganz (1972, see also Baron et al., 1974) found that internals achieved a better performance than externals when task-supplied feedback was presented. On the other hand, externals showed a better performance than internals when feedback was given by an experimenter. As expected, internals responded more conspicuously to task-supplied feedback, whereas externals were more influenced by personal feedback. In addition, it was shown that people with external LOC exhibited more symptoms of depression, demonstrating less satisfaction and less effort following failure feedback. (Basgall, Snyder, 1988; Weiss, Sherman, 1973). Therefore, we assumed that internals would show a better performance than externals following task-supplied positive and negative feedback.

Neuroticism: According to research on neuroticism in feedback, relatively few studies have examined whether neuroticism af- fects the impact of feedback on performance. In particular the relationship to negative feedback interventions was examined. It was shown that a high level of neuroticism caused a debilitating effect on performance after receiving immediate negative feedback, whereas after positive feedback no effect was revealed (Moeller, Robinson, 2010; Robinson, Moeller, Fetterman, 2010). Gomez, Cooper, and Gomez (2000) found that emotionally stable individuals were less affected by immediate negative feedback inducing punishment than highly neurotic participants. Therefore, they argued that performances of emotionally stable persons should be less affected by negative feedback.

Based on the empirical results across the four traits we assumed that CSE would affect the impact of positive and negative feedback. We hypothesized that participants possessing a high level of CSE would perform better than low CSE individuals (H1) after negative task-supplied feedback (H1). In addition, after positive task-supplied feedback, high CSE individuals will improve their performance more than those with a low level of CSE (H2). The second hypothesis was generated even though there is no empirical evidence for a differential impact of positive feedback concerning neuroticism. We assumed that the breadth of CSE should reveal the questioned effect mainly based on the impact of GSE, SE and LOC.

\section{METHOD}

\section{Participants}

The study was conducted with 471 subjects participating in exchange for minimal course credit. The participants were students 
of sport science ( $\mathrm{n}=235$; 118 male, $117 \mathrm{fe}$ male) and students pursuing a teaching certification in the subjects of sport science and psychology $(n=236 ; 83 \text { male, } 153 \text { female })^{1}$. Participants' average age was 22.23 (SD = 3.84) years.

\section{Procedure}

The study consisted of two phases. In the first phase participants completed an online questionnaire within a time frame of four weeks. Subsequently, the second phase began and was conducted under laboratory conditions. Participants were assigned to one of three feedback conditions: Receiving no feedback (control group; $n=69$ ), negative feedback $(\mathrm{n}=200)$ or positive feedback $(\mathrm{n}=$ 202). After reading and signing a consent form, participants were told that all instructions would be administered using a computer program. During the experiment, a supervisor stayed in the laboratory to assist with any arising problems or questions. To facilitate the experiment, subjects were told that the research was about the construction of a test designed to measure selective attention. We informed them about the actual goal of our research at the end of the term (debriefing).

\section{Measures}

The questionnaires assessing GSE, SE, LOC and neuroticism were selected from pilot studies claiming to reconstruct the model of CSE economically, and with regard to their separate measurements. The assessment of

\footnotetext{
${ }^{1}$ The two groups did not differ in CSE or the impact of feedback. Thus, data analysis is reported for the total sample only.
}

single scale measures was preferred because of the possibility of reanalyzing the model of CSE as well as questioning the interrelatedness and asymmetrical roles of single CSE traits (cf., Chang et al., 2012; Dormann et al., 2006; Gardner, Pierce, 2009; Johnson et al., 2008).

Generalized self-eficacy: The General Selfefficacy Scale developed by Schwarzer and Jerusalem (1999) was administered. This scale consists of ten items, where responses are recorded on a 4-point scale $(1=$ not at all true, 4 = absolutely true). The internal consistency was Cronbach's $\alpha=.79$.

Self-esteem: The subscale Self-Concept of the Questionnaire for Competence and Control Orientations (Krampen, 1991) assessing individual self-concept of one's own competence was administered. This scale consists of eight items and represents a global and one-dimensional measurement of individuals' belief in their competence, which can be used as a measure for global self-esteem (cf., Marsh, Parada, Ayotte, 2004). Responses were given on a 6 -point scale $(1=$ not at all true, $6=$ very true). Internal consistency (Cronbach's $\alpha$ ) was .78.

Locus of control: Two other scales of the Questionnaire for Competence and Control Orientations (Krampen, 1991) were administered. The scales assess internality and powerful others control, each consisting of eight items. Cronbach's $\alpha$ were 70 (internality) and .76 (powerful others control). To produce a one-dimensional scale of an internal (high scores) and external (low scores) locus of control the cumulative value of the scale powerful others control was subtracted from the cumulative value internality.

Neuroticism: A 6-item subscale of the Frankfurt Self-Concept Scale (Deusinger, 1986), which assesses the individual self- 
concept of susceptibility and mood, was conducted. This scale enables the assessment of neuroticism, where a high score reflects a low level of neuroticism. Response options consisted of a 6-point scale ranging from 1 (strongly agree) to 6 (strongly disagree). The internal consistency was Cronbach's $\alpha=.76$.

Test performance: To investigate the impact of feedback on performance, we chose a task measuring selective attention. The items represented short video clips showing different kinds of sports, which were selected from television broadcast. The subjects' task was to indicate via keyboard the number of athletes that appeared during a clip. The number of athletes appearing ranged from at least four to nine. The difficulty was in distinguishing between active athletes and referees, substitutes as well as viewers off the court. Moreover, the duration of the presented video clips (1941 milliseconds), and the reaction time (2000 milliseconds) were limited. After the reaction of the test person or lapse of time, the next video clip was started. The particular duration of 1941 milliseconds resulted from specific characteristics of the software programs for editing and from presenting the video clips. Altogether, two tests, consisting of 15 items each, were administered consecutively. After the first test a manipulated feedback intervention was implemented.

Feedback manipulation: The current study was restricted to the investigation of the impact of normative positive and normative negative feedback. Thus, we manipulated the feedback interventions irrespective of the actual performance and referred it to a social norm. To do so, we established a standard of performance: At the beginning of the test, subjects received information about the performance average in the upcoming test (e.g., the average performance represents the correct response to eight out of 15 items). The feedback interventions were related to this standard: In the case of negative feedback, subjects were told that they had given two or three correct responses and that their performance was explicitly inferior to average performance. In the positive feedback condition, participants were told that they had given 13 or 14 correct answers and that their performance was explicitly superior to average performance.

Following the feedback intervention, participants had to decide how to proceed by choosing from predetermined options. They could either raise the standard, maintain the standard or abort. To maintain the standard represented the choice of a test at the same level of difficulty. Raising the standard meant increasing the level of difficulty: Participants were told that the subsequent test would be more difficult than the previous one and that the task standard would be higher. This information was simulated and participants received the same test as those who chose to maintain the standard. This deception was necessary in order to enable the comparison of test performances corresponding to different decisions. The decision behavior was assessed with regard to its significant impact on the effectiveness of feedback interventions (Hattie, Timperley, 2007; Ilies, Judge, 2005; Kluger, DeNisi, 1996; VandeWalle, Cron, Slocum Jr, 2001). Participants of the control group did not receive performance feedback after the first test. Therefore, demanding decision behavior (abort, maintain or raise the standard) did not seem reasonable for this group, which led to the drawing of a smaller control sample. 


\section{RESULTS}

\section{The Model of CSE}

At first, the concept of CSE was examined. We analyzed the correlations between the concepts of GSE, SE, LOC and emotional stability. As can be seen in Table 1, the correlations among the four traits were satisfying and similar to those reported by Judge et al. (2002). However, the correlation between locus of control and neuroticism turned out to be low. Therefore, we initially conducted a principal component analysis at the scale level. The four scales loaded on one factor, which explained $60.11 \%$ of variance in the scales. The loadings of the measures were convenient and therefore recommended the concept of CSE. To enable an even more specific analysis of CSE, we conducted a maximum likelihood confirmatory factor analysis at the scale level. The fit indices turned out to be strong $\left(\chi^{2}(2 \mathrm{df})=.66, \mathrm{p}=.72\right.$; $\mathrm{GFI}=.99$, $\mathrm{NFI}=.99, \mathrm{NNFI}=1.00, \mathrm{CFI}=1.00, \mathrm{RMSEA}<$ $.001)$. As expected, one factor comprised the four scales of GSE, SE, LOC and emotional stability. Therefore, we concluded that the model of CSE fits the data well.

\section{CSE and the Impact of Feedback}

In the second step, the role ofCSE concerning the impact of positive and negative feed- back was examined. We conducted $2 \times 2 \times 3 \times$ 3 partially hierarchical repeated measures ANCOVA: Time (test before vs. after feedback) was included as within-subjects factor. The performances in both tests were assessed by the sum of correct answers. Gender, feedback condition (positive, negative, no feedback) and decision behavior (raise the standard, maintain the standard, no choice) were implemented as between-subjects factors. However, decision behavior was nested in feedback condition, because it was demanded exclusively following negative or positive feedback. CSE was incorporated as covariate. A factor score of CSE was created by multiplying the scales by their factor weights.

Feedback: The main effect of feedback condition in ANCOVA turned out to be not significant $(\mathrm{F}(2,461)=1.43, \mathrm{p}=.23)$. However, ANCOVA revealed the expected Time $\mathrm{x}$ Feedback interaction $(\mathrm{F}(2,461)=6.93, \mathrm{p}<$ $\left..001, \eta^{2}=.03\right)$. Scheffé post hoc tests showed that negative $(\mathrm{p}<.001)$ and positive feedback $(\mathrm{p}<.001)$ caused a significant performance enhancement from pre-test to posttest, whereas this was not revealed for control group $(\mathrm{p}=.88)$. In addition, participants receiving positive feedback increased their performance more than those receiving negative feedback $(\mathrm{p}<.001)$. Table 2 shows the means and standard deviations for Test 1 and Test 2 considering feedback condition, gender and CSE. Figure 1 illustrates the effects of feedback condition.

Table 1. Correlations and factor loadings of core self-evaluation concepts $(\mathrm{N}=471)$

\begin{tabular}{|l|c|c|c|c|}
\hline & Factor loadings & 2 & 3 & 4 \\
\hline 1. General self-efficacy & .82 & $.61^{*}$ & $.46^{*}$ & $.43^{*}$ \\
\hline 2. Self-esteem & .84 & & $.47^{*}$ & $.46^{*}$ \\
\hline 3. Locus of control & .73 & & & $.35^{*}$ \\
\hline 4. Emotional stability & .71 & & & \\
\hline
\end{tabular}

Note: $* p \leq .001$ 
Table 2. Means (M) and Standard Deviations (SD) in Test 1 and Test 2 for feedback condition, gender and CSE

\begin{tabular}{|l|c|c|c|c|c|}
\hline \multirow{2}{*}{} & \multirow{2}{*}{$\mathrm{n}$} & \multicolumn{2}{|c|}{ Test 1 } & \multicolumn{2}{c|}{ Test 2 } \\
\cline { 3 - 6 } & & $\mathrm{M}$ & $\mathrm{SD}$ & $\mathrm{M}$ & $\mathrm{SD}$ \\
\hline Feedback condition & 202 & 6.91 & 2.31 & 8.44 & 2.55 \\
\hline Positive & 200 & 6.82 & 2.51 & 7.72 & 2.74 \\
\hline Negative & 69 & 7.57 & 2.42 & 8.01 & 2.56 \\
\hline No Feedback & 200 & 6.63 & 2.31 & 7.47 & 2.52 \\
\hline Gender & 7.44 & 2.50 & 8.90 & 2.61 \\
\hline male & 271 & 6.70 & 2.49 & 7.53 & 2.60 \\
\hline female & 233 & 7.22 & 2.33 & 8.61 & 2.60 \\
\hline CSE & 238 &
\end{tabular}

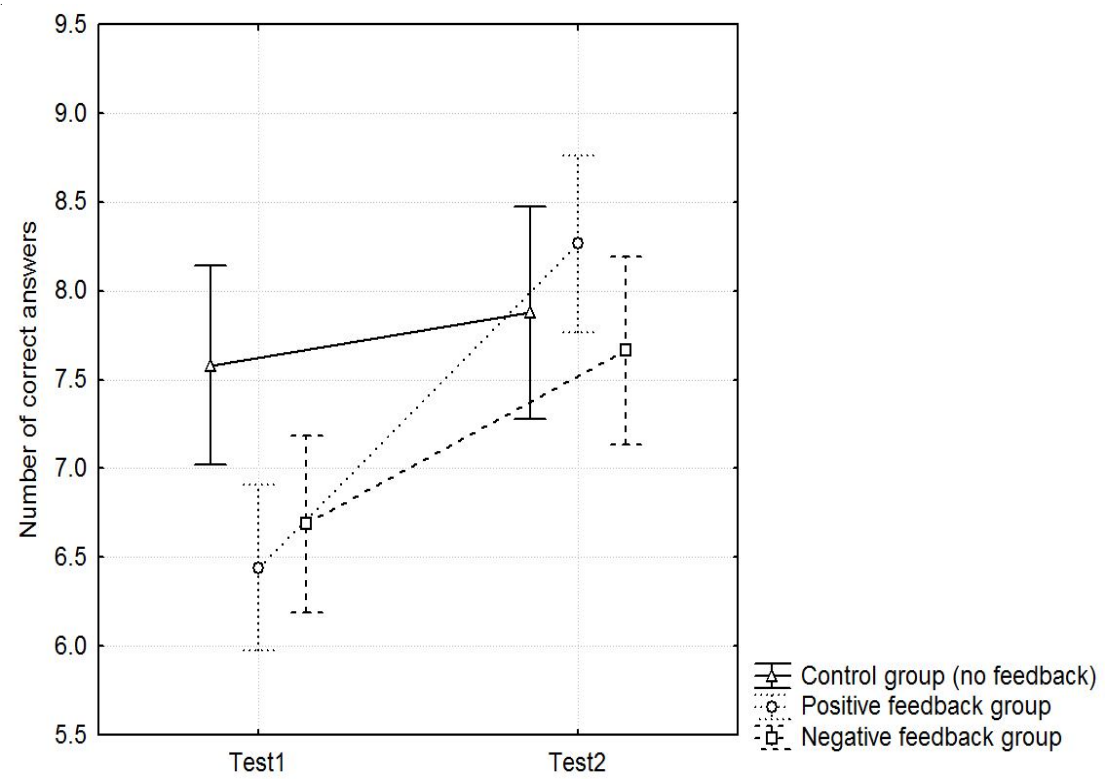

Figure 1. Performances in the first and second test (means and 95\% confidence intervals) for each feedback condition 
Decision behavior: ANCOVA showed a significant main effect of decision behavior (nested in feedback condition; $\mathrm{F}(2,461)$ = $\left.5.15, \mathrm{p}=.01, \eta^{2}=.02\right)$. Participants who raised the standard showed a higher performance before and after feedback than those who maintained the standard. However, the interaction term Time $x$ Decision behavior turned out to be not significant $(F(2,461)=.77, p=$ .46).

Gender: The main effect of gender $\left(\mathrm{F}(1,461)=10.23, \mathrm{p} .001, \eta^{2}=.02\right)$ as well as the interaction of gender and time $(\mathrm{F}(1,461)$ $\left.=7.00, \mathrm{p}=.01, \eta^{2}=.01\right)$ turned out to be significant. Scheffé post hoc tests showed that male participants performed better than females in Test $1(p=.03)$ and increased their performance more in Test $2(\mathrm{p}<.001)$. However, ANCOVA did not reveal a significant interaction of gender and feedback $(\mathrm{F}(2,461)$ $=1.72, \mathrm{p}=.18)$, nor of Time $\mathrm{x}$ Gender $\mathrm{x}$ Feedback condition $(\mathrm{F}(2,461)=2.26, \mathrm{p}=.11)$.

CSE: Concerning the role of CSE, ANCOVA revealed a significant impact $(\mathrm{F}(1,461)=9.25$, $\left.\mathrm{p}<.01, \eta^{2}=.02\right)$ and a significant interaction of Time $x \operatorname{CSE}\left(F(1,461)=4.67, p=.03, \eta^{2}=\right.$ $.01)$. Thus, CSE significantly affected the performances in both tests. Participants high in CSE achieved a higher performance level and were more able to enhance their performance in Test 2 than those low in CSE. To receive more information concerning the relation of CSE and feedback, we conducted a repeated measures ANOVA disregarding CSE as covariate. Comparing the amount of variation accounted for by the interaction term Time $\mathrm{x}$ Feedback it was shown that when controlling the effect of CSE on the performances in both tests the interaction accounted for 4.01 units (sum of squares) more than disregarding CSE (ANCOVA: $\mathrm{SS}_{\text {TIME*FEEDBACK }}=48.06, \mathrm{SS}_{\mathrm{R}}=1599.45$;
ANOVA: $\mathrm{SS}_{\text {TIME*FEEDBACK }}=44.06, \mathrm{SS}_{\mathrm{R}}=$ 1615.66). Thus, CSE had an impact on the power of feedback but merely to a very small amount. To enable a more hypotheses-oriented analysis of the data and a more purposive examination of CSE concerning feedback repeated measures ANOVA was redone considering CSE as dichotomous variable (median split). Multiple regression analysis was not conducted considering the arising number of predictors (dummy coding \& interactional terms) and their interrelations. ANOVA reconfirmed the reported results of ANCOVA but did not reveal a significant interaction of time, feedback and $\operatorname{CSE}(\mathrm{F}(2,456)$ $=.28, \mathrm{p}=.75)$. Therefore, we had to reject our hypotheses: The results revealed merely a small, and therefore not meaningful, impact of CSE on the effects of feedback.

\section{The Single CSE Traits and the Impact of Feedback}

By refusing the hypothesis concerning CSE, we were interested in analyzing singular traits of CSE according to their impact on feedback effects. Therefore, we conducted a repeated measures ANOVA including the four traits of GSE, SE, LOC, neuroticism (median split) and feedback condition (positive, negative, no feedback) as between-subjects factors. Decision behavior and gender were excluded considering the large number of independent variables. ANOVA revealed that solely SE showed a significant interaction with feedback condition and time $(\mathrm{F}(2,438)=$ $\left.3.40, \mathrm{p}=.03, \eta^{2}=.02\right)$. Table 3 presents the means and standard deviations for Test 1 and Test 2 with regard to feedback condition and SE. Figure 2 illustrates the different performances in the first and second test in relation to feedback condition and SE. Scheffé 
Table 3. Means (M) and Standard Deviations (SD) in the first and second test considering feedback condition and self-esteem

\begin{tabular}{|l|c|c|c|c|c|c|}
\hline \multirow{2}{*}{ Feedback condition } & \multirow{2}{*}{$\begin{array}{c}\text { Self- } \\
\text { Esteem* }\end{array}$} & \multirow{2}{*}{$\mathrm{n}$} & \multicolumn{2}{|c|}{ Test 1 } & \multicolumn{2}{c|}{ Test 2 } \\
\cline { 4 - 7 } & 1 & 109 & 6.85 & 2.27 & 8.35 & 2.49 \\
\hline \multirow{2}{*}{ Positive } & 2 & 93 & 6.97 & 2.37 & 8.55 & 2.62 \\
\hline \multirow{2}{*}{ Negative } & 1 & 100 & 6.57 & 2.52 & 7.04 & 2.79 \\
\cline { 2 - 7 } & 2 & 99 & 7.08 & 2.50 & 8.41 & 2.53 \\
\hline \multirow{2}{*}{ No feedback } & 1 & 24 & 7.71 & 2.49 & 7.38 & 2.12 \\
\cline { 2 - 7 } & 2 & 45 & 7.51 & 2.40 & 8.36 & 2.73 \\
\hline
\end{tabular}

Note: *Self-esteem: 1 = low self-esteem, 2 = high self-esteem
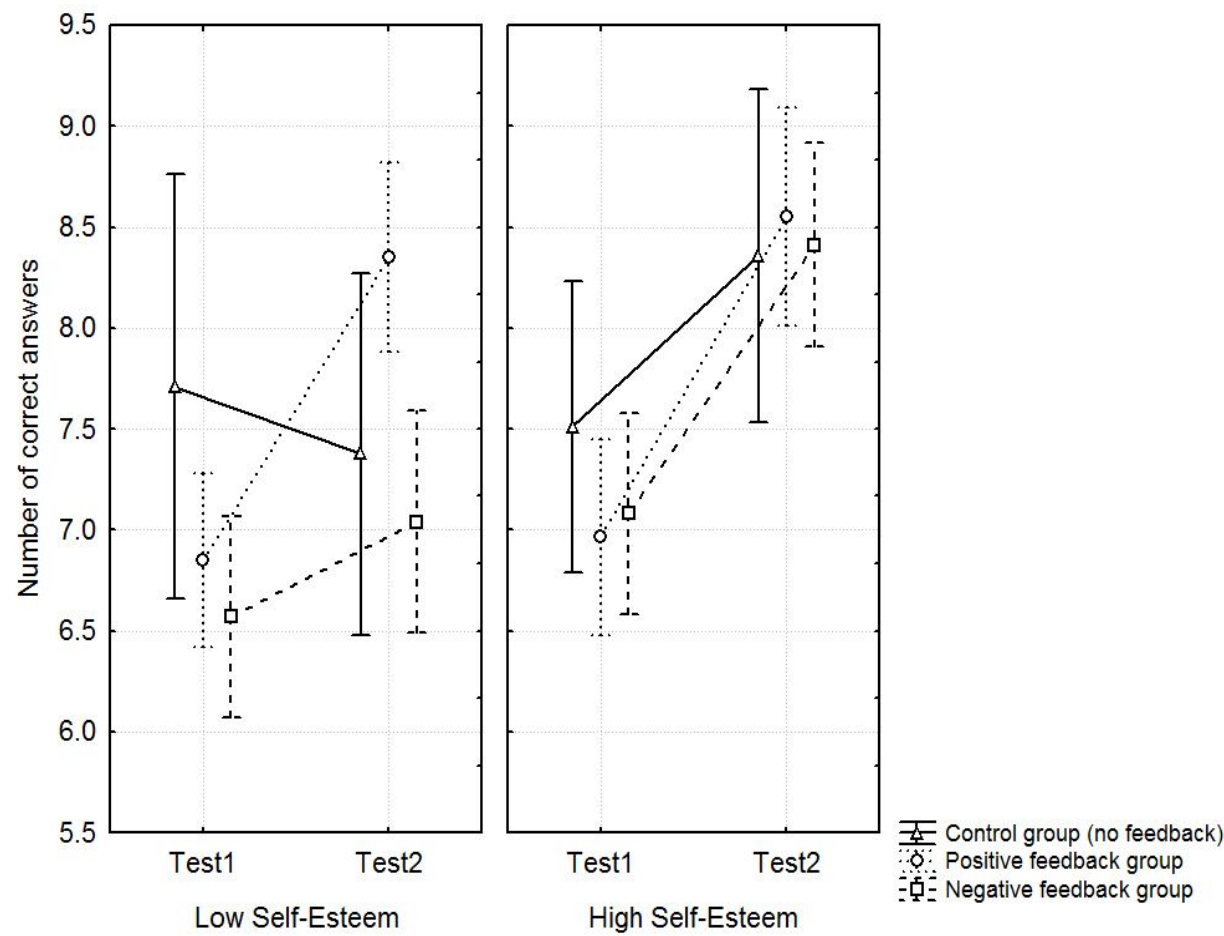

Figure 2. Performances in the first and second test (means and 95\% confidence intervals) with regard to feedback condition and self-esteem 
post hoc tests clarified that participants with low SE receiving negative feedback showed a worse performance in Test 1 than those with high SE in Test 2 (no feedback: $p<.001$; positive feedback: $p=.01$; negative feedback: $\mathrm{p}=.01)$ and those with low SE receiving positive feedback before Test $2(p=.01)$. In addition, the differences between Test 1 and Test 2 for participants high in SE proved significant following positive $(\mathrm{p}<.001)$ and negative feedback $(\mathrm{p}=.01)$.

The interactional effects of $\operatorname{GSE}(\mathrm{F}(2,438)$ $=1.24, \mathrm{p}=.29), \operatorname{LOC}(\mathrm{F}(2,438)=1.49, \mathrm{p}=.23)$ and neuroticism $(\mathrm{F}(2,438)=1.31, \mathrm{p}=.27)$ with feedback condition and time was revealed to be not significant, neither were any four-way interactions. Five-way and six-way interactions were not conducted because of minor sample sizes in selected cells.

\section{DISCUSSION}

The aim of the current study was to analyze the influence of CSE on the impact of positive and negative normative feedback. At first, the fit of the CSE model was examined. In comparison to the average correlations listed in the meta-analysis of Judge et al. (2002), the correlation between GSE and SE (.61; Judge et al., 2002: .85) proved to be deviant. We assume that this discrepancy could emerge from the differential measurements of self-esteem. In addition, the correlation between LOC and emotional stability turned out to be low and cast doubt on the concept of CSE. However, lower correlations between both traits were observed before and suggest CSE traits to be not interchangeable (Chang et al., 2012; Dormann et al., 2006; Johnson et al., 2011; Johnson et al., 2008; Judge et al., 2002). Rather, the model of CSE seems to be an aggregate construct based on causal indicators. It has to be mentioned that we did not control social desirability and common method variance in this study. Thus, we were not able to make a substantial contribution to deepen the understanding of the CSE model. Our results have to be limited to these failings. Further studies have to pick up the mentioned concerns and try to clarify the structure of CSE more comprehensively. Nonetheless, the results of the principal component analysis as well as the fit indices of the confirmatory factor analysis were promising in our study and supported the replication of the CSE model in the collected data.

A partially hierarchical repeated measures ANCOVA revealed merely a small impact of CSE on the effects of positive and negative feedback. Following up this result, ANOVA did not turn out any significant difference between participants high and low in CSE. Thus, we had to reject both hypotheses: CSE did not affect the impact of positive or negative feedback. Possibly, CSE represents too broad a factor and thus, a less specific variable to moderate the power of feedback (Chang et al., 2012; Johnson et al., 2012). Previous studies mostly demonstrated small effects of personality traits on the impact of feedback interventions (Hattie, Timperley, 2007; Kluger, DeNisi, 1996; Mory, 2004). Therefore, these small effects may intensify when regarding a broader personality factor, as we expected based on previous results, or may diminish when having an effect in slightly different directions. However, it was found that participants high in CSE achieved a better performance in test 1 and additionally increased their performance more in test 2 than those low in CSE. We conclude that these effects were caused by the positive relationship between CSE and motivation (cf., Chang et al., 2012; Bono, Judge, 2003; Erez, 
Judge, 2001). In this regard, participants high in CSE could have been more strongly motivated to achieve performance in the test construction. Also, feedback condition and gender turned out to have a significant impact on performance: Positive feedback caused a stronger increase in performance than negative feedback. This result is in line with past research (Hattie, Timperley, 2007; Kluger, DeNisi, 1996; Shute, 2008). In addition, male participants performed better than women in the first and second test. We suppose that the chosen task disadvantaged women compared to men, although preliminary studies did not reveal such effects. In this regard, a stronger motivation concerning the task could again have been manifested by men and caused better performances in test 1 and test 2 . Thus, the ability to generalize our findings has to be limited in relation to the chosen task and a possibly stronger appeal to men. However, we did not reveal any significant interaction of gender and CSE and/or feedback.

By rejecting the hypothesis concerning CSE, the separate impact of the traits GSE, SE, LOC and neuroticism on the effects of feedback was examined. SE alone turned out to affect the impact of feedback. We found that participants with low SE receiving negative feedback did not enhance performance in test 2. Contrastingly, participants with high SE irrespective of their feedback condition, as well as those with low SE who received positive feedback, increased their performance significantly. In this regard, participants high in SE profited from positive as well as negative feedback and improved their performance. This result was also observed for those low in SE receiving positive feedback, whereas participants with low SE receiving negative feedback merely maintained performance. This finding tied in with the results of several studies (Brockner et al., 1987; Brown, 2010; Fedor et al., 2001; Shrauger, Rosenberg, 1970).

However, we did not find any impact of GSE, LOC or neuroticism. These traits did not explain any additional variance of the performances after the feedback interventions. We assume that this could be caused by providing feedback just once between two short tests. In many studies the impact of feedback was examined considering several feedback interventions (e.g., Baron, Ganz, 1972; Di Paula, Campbell, 2002; Heslin, Latham, 2004; Moeller, Robinson, 2010; Robinson et al., 2010). It seems probable that the effect of feedback increases by receiving several feedback interventions, for instance across several feedback loops. Thus, by enlarging the effect of feedback the impact of personality traits on this effect could also increase disproportionately. This could also explain the lack of any interaction between CSE and feedback. However, the power of feedback has been shown to be determined by its style as well the characteristics of the task (Hattie, Timperley, 2007; Kluger, DeNisi, 1996; Lipnevich, Smith, 2009; Mory, 2004; Shute, 2008). Thus, the findings of the current study have to be restricted to this, providing single normative feedback interventions between two tests comprising attentional tasks. In this regard, further research has to clarify the role of CSE regarding different feedback interventions as well as different tasks.

Received July 3, 2012

\section{REFERENCES}

BANDURA, A., 1997, Self-efficacy: The exercise of control. New York: Freeman. 
BANDURA, A., CERVONE, D., 1983, Self-evaluative and self-efficacy mechanisms governing the motivational effects of goal systems. Journal of Personality and Social Psychology, 45, 1017-1028. doi:10.1037/0022-3514.45.5.1017

BANGERT-DROWNS, R.L., KULIK, C.-L.C., KULIK, J.A., MORGAN, M., 1991, The instructional effect of feedback in test-like events. Review of Educational Research, 61, 213-238. doi:10.3102 /00346543061002213

BARON, R.M., COWAN, G., GANZ, R.L., McDONALD, M., 1974, Interaction of locus of control and type of performance feedback: Considerations of external validity. Journal of Personality and Social Psychology, 30, 285-292. doi: $10.1037 / \mathrm{h} 0036662$

BARON, R.M., GANZ, R.L., 1972, Effects of locus of control and type of feedback on the task performance of lower-class black children. Journal of Personality and Social Psychology, 21, 124-130. doi:10.1037/h0032099

BASGALL, J.A., SYNDER, C.R., 1988, Excuses in waiting: External locus of control and reactions to success-failure feedback. Journal of Personality and Social Psychology, 54, 656-662. doi:10.1037/ 0022-3514.54.4.656

BAUMEISTER, R.F., CAMPBELL, J.D., KRUEGER, J.I., VOHS, K.S., 2003, Does high selfesteem cause better performance, interpersonal success, happiness, or healthier lifestyles? Psychological Science in the Public Interest, 4, 1-44. doi: 10.1111/1529-1006.01431

BERNICHON, T., COOK, K.E., BROWN, J.D., 2003, Seeking self-evaulative feedback: The interactive role of global self-esteem and specific selfviews. Journal of Personality and Social Psychology, 84, 194-204. doi:10.1037/0022-3514.84.1. 194

BONO, J.E., COLBERT, A.E., 2005, Understanding responses to multi-source feedback: The role of core self-evaluations. Personnel Psychology, 58, 171-203. doi: 10.1111/j.1744-6570.2005.00633.x

BONO, J.E., JUDGE, T.A., 2003, Core self-evaluations: A review of the trait and its role in job satisfaction and job performance. European Journal of Personality, 17, 5-18. doi:10.1002/per.481

BROCKNER, J., DERR, W.R., LAING, W.N., 1987, Self-esteem and reactions to negative feedback: Toward greater generalizability. Journal of Research in Personality, 21, 318-333. doi:10.1016/ 0092-6566(87)90014-6

BROWN, J.D., 2010, High self-esteem buffers negative feedback: Once more with feeling. Cogni- tion \& Emotion, 24, 1389-1404. doi:10.1080/ 02699930903504405

CHANG, C.-H., FERRIS, D.L., JOHNSON, R.E., ROSEN, C.C., TAN, J.A., 2012, Core self-evaluations: A review and evaluation of the literature. Journal of Management, 38, 81-128. doi: 10.1177/ 0149206311419661

CHEN IDSON, L., HIGGINS, E.T., 2000, How current feedback and chronic effectiveness influence motivation: Everything to gain versus everything to lose. European Journal of Social Psychology, 30, 583-592. doi: 10.1002/1099-0992(200007 /08)30:4

CLARIANA, R.B., WAGNER, D., ROHER MURPHEY, L.C., 2000, Applying a connectionist description of feedback timing. Educational Technology Research and Development, 48, 5-21. doi: $10.1007 / \mathrm{bf0} 2319855$

DEUSINGER, I.M., 1986, Frankfurter Selbstkonzeptskalen (FSKN). Handanweisung [Frankfurt SelfConcept Scales. Manual]. Göttingen, Germany: Hogrefe.

DI PAUlA, A., CAMPBELL, J.D., 2002, Selfesteem and persistence in the face of failure. Journal of Personality and Social Psychology, 83, 711724. doi:10.1037/0022-3514.83.3.711

DORMANN, C., FAY, D., ZAPF, D., FRESE, M., 2006, A state-trait analysis of job satisfaction: On the effect of core self-evaluations. Applied Psychology: An International Review, 55, 27-51. doi: 10.1111/j.1464-0597.2006.00227.x

EREZ, A., JUDGE, T.A., 2001, Relationship of core self-evaluations to goal setting, motivation, and performance. Journal of Applied Psychology, 86, 1270-1279. doi:10.1037/0021-9010.86.6. 1270

FEDOR, D.B., DAVIS, W.D., MASLYN, J.M., MATHIESON, K., 2001, Performance improvement efforts in response to negative feedback: The roles of source power and recipient self-esteem. Journal of Management, 27, 79-97. doi:10.1177/ 014920630102-700105

FÖRSTER, J., GRANT, H., IDSON, L.C., HIGGINS, E.T., 2001, Success/failure feedback, expectancies, and approach/avoidance motivation: How regulatory focus moderates classic relations. Journal of Experimental Social Psychology, 37, 253-260. doi: 10.1006/jesp.2000.1455

GARDNER, D.G., PIERCE, J.L., 2009, The core self-evaluation scale: Further construct validation evidence. Educational and Psychological Measurement, 70, 291-304. doi: 10.1177/ 0013164409344505 
GOMEZ, R., COOPER, A., GOMEZ, A., 2000, Susceptibility to positive and negative mood states: Test of Eysenck's, Gray's and Newman's theories. Personality and Individual Differences, 29, 351365. doi:10.1016/s0191-8869(99)00198-1

HATTIE, J., TIMPERLY, H., 2007, The power of feedback. Review of Educational Research, 77, 81-112. doi:10.3102/003465430298487

HEIMPEL, S.A., WOOD, J.V., MARSHALL, M.A., BROWN, J.D., 2002, Do people with low self-esteem really want to feel better? Self-esteem differences in motivation to repair negative moods. Journal of Personality and Social Psychology, 82, 128-147. doi:10.1037/0022-3514.82.1.128

HESLIN, P.A., LATHAM, G.P., 2004, The effect of upward feedback on managerial behavior. Applied Psychology, 53, 23-37. doi:10.1111/j.14640597.2004.00159.x

ILGEN, D.R., FISHER, C.D., TAYLOR, M.S., 1979, Consequences of individual feedback on behavior in organizations. Journal of Applied Psychology, 64, 349-371. doi:10.1037/0021-9010.64 4.349

ILIES, R., JUDGE, T.A., 2005, Goal regulation across time: The effects of feedback and affect. Journal of Applied Psychology, 90, 453-467. doi:10.1037/0021-9010.90.3.453

JOHNSON, R.E., ROSEN, C.C., CHANG, C.-H., DJURDJEVIC, E., TAING, M.U., 2012, Recommendations for improving the construct clarity of higher-order multidimensional constructs. Human Resource Management Review, 22, 62-72. doi: 10.1016/j.hrmr.2011.11.006

JOHNSON, R.E., ROSEN, C.C., DJURDJEVIC, E., 2011, Assessing the impact of common method variance on higher order multidimensional constructs. Journal of Applied Psychology, 96, 744761. doi: $10.1037 / \mathrm{a} 0021504$

JOHNSON, R.E., ROSEN, C.C., LEVY, P.E., 2008, Getting to the core of core self-evaluation: A review and recommendations. Journal of Organizational Behavior, 29, 391-413. doi: 10.1002/ job. 514

JUDGE, T.A, EREZ, A., BONO, J.E., THORESEN, C.J., 2002, Are measures of self-esteem, neuroticism, locus of control, and generalized self-efficacy indicators of a common core construct? Journal of Personality and Social Psychology, 83, 693-710. doi:10.1037/0022-3514.83. 3.693

JUDGE, T.A., LOCKE, E.A., DURHAM, C.C., 1997, The dispositional causes of job satisfaction: A core evaluations approach. Research in Organi- zational Behavior, 19, 151-188. Retrieved from http://www.timothy-judge.com/ROB.pdf

JUDGE, T.A., LOCKE, E.A., DURHAM, C.C., KLUGER, A.N., 1998, Dispositional effects on job and life satisfaction: The role of core evaluations. Journal of Applied Psychology, 83, 17-34. doi: 10.1037/0021-9010.83.1.17

KAMER, B., ANNEN, H., 2010, The role of core self-evaluations in predicting performance appraisal reactions. Swiss Journal of Psychology, 69, 95-104. doi:10.1024/1421-0185/a000011

KARL, K.A., O'LEARY-KELLY, A.M., MARTOCCHIO, J.J., 1993, The impact of feedback and self-efficacy on performance in training. Journal of Organizational Behavior, 14, 379-394. doi: 10.1002/job.4030140409

KINICKI, A.J., PRUSSIA, G.E., WU, B., McKEERYAN, F.M., 2004, A covariance structure analysis of employees' response to performance feedback. Journal of Applied Psychology, 89, 1057-1069. doi:10.1037/0021-9010.89.6.1057

KLUGER, A.N., DeNISI, A., 1996, The effects of feedback intervention on performance: A historical review, a meta-analysis and a preliminary feedback intervention theory. Psychological Bulletin, 119, 254-284. doi:10.1037/0033-2909.119. 2.254

KRAMPEN, G., 1991, Fragebogen zu Kompetenz- und Kontrollüberzeugungen (FKK) [Questionnaire for Competence and Control Orientations]. Göttingen, Germany: Hogrefe.

LIPNEVICH, A.A., SMITH, J.K., 2009, Effects of differential feedback on students' examination performance. Journal of Experimental Psychology: Applied, 15, 319-333. doi:10.1037/a0017841

LONDON, M., SMITHERS, J.W., 1995, Can multi-source feedback change perceptions of goal accomplishment, self-evaluations, and performancerelated outcomes? Theory-based applications and directions for research. Personnel Psychology, 48, 803-839. doi:10.1111/j.1744-6570.1995.tb01782 . $\mathrm{x}$

MAGILL, R.A., 2001, Augmented feedback in motor skill acquisition. In: R.N. Singer, H.A. Hausenblas, C. Janelle (Eds.), Handbook of Sport Psychology (pp. 86-114). New York: Wiley.

MARSH, H.W., PARADA, R.H., AYOTTE, V., 2004, A multidimensional perspective of relations between self-concept (self description questionnaire II) and adolescent mental health (youth self-report). Psychological Assessment, 16, 27-41. doi:10.1037/1040-3590.16.1.27 
McCARTHY, A.M., GARAVAN, T.N., 2007 , Understanding acceptance of multisource feedback for management development. Personnel Psychology, 36, 903-917. doi:10.1108/ 00483480710822427

MOELLER, S.K., ROBINSON, M.D., 2010 Cognitive sources of evidence for neuroticism's link to punishment-reactivity processes. Cognition \& Emotion, 24, 741-759. doi:10.1080/ 02699930902978436

MORY, E.H., 2004, Feedback research revisited. In: D. Jonassen (Ed.), Handbook of research on educational communications and technology (pp. 745-783). Mahwah, NJ: Erlbaum.

NARCISS, S., 2008, Feedback strategies for interactive learning tasks. In: J.M. Spector, M.D. Merrill, J.J.D. van Merrienboer, M.P. Driscoll (Eds.), Handbook of research on educational communications and technology (pp. 125-143). Mahwah, NJ: Lawrence Erlbaum Associates.

PODSAKOFF, P.M., FARTH, J.-L., 1989, Effects of feedback sign and credibility on goal setting and task performance. Organizational Behavior and Human Decision Processes, 44, 45-67. doi:10.1016/0749-5978(89)90034-4

ROBINSON, M.D., MOELLER, S.K., FETTERMAN, A.K., 2010, Neuroticism and responsiveness to error feedback: Adaptive self-regulation versus affective reactivity. Journal of Personality, 78, 1469-1496. doi:10.1111/j.14676494.2010.00658.x

SCHWARZER, R., JERUSALEM, M. (Eds.), 1999, Skalen zur Erfassung von Lehrer- und Schülermerkmalen. Dokumentation der psychometrischen Verfahren im Rahmen der Wissenschaftlichen Begleitung des Modellversuchs Selbstwirksame Schulen [Scales for the assessment of teacher and student characteristics. Documentation of the psychometric methods regarding the scientific monitoring of the pilot project self-efficient schools]. Berlin: Freie Universität Berlin.

SHRAUGER, J.S., ROSENBERG, S.E., 1970, Selfesteem and the effects of success and failure feedback on performance. Journal of Personality, 38, 404-417. doi:10.1111/j.1467-6494.1970.tb00018 . $\mathrm{x}$

SHUTE, V.J., 2008, Focus on formative feedback. Review of Educational Research, 78, 153189. doi: $10.3102 / 0034654307313795$

SMITHER, J.W., LONDON, M., REILLY, R.R., 2005 , Does performance improve following multisource feedback? A theoretical model, meta-analysis, and review of empirical findings. Personnel Psychology, 58, 33-66. doi:10.1111/j.1744-6570.2005 $.514 \_1 . \mathrm{x}$

STUMPP, T., MUCK, P.M., HÜLSHEGER, U.R., JUDGE, T.A., MAIER, G.W., 2010, Core self-evaluations in Germany: Validation of a German measure and its relationship with career success. Applied Psychology: An International Review, 59, 674-700. doi: 10.1111/j.1464-0597.2010.00422.x

VANDEWALLE, D., CRON, W.L., SLOCUM Jr, J.W., 2001, The role of goal orientation following performance feedback. Journal of Applied Psychology, 86, 629-640. doi:10.1037/0021-9010.86. 4.629

VAN-DIJK, D., KLUGER, A.N., 2004, Feedback sign effect on motivation: Is it moderated by regulatory focus? Applied Psychology, 53, 113-135. doi: $10.1111 / \mathrm{j} .1464-0597.2004 .00163 . \mathrm{x}$

WEISS, H., SHERMAN, J., 1973, Internal-external control as a predictor of task effort and satisfaction subsequent to failure. Journal of Applied Psychology, 57, 132-136. doi:10.1037/h0037054 


\title{
INDIVIDUÁLNE ROZDIELYV DOPADE SPÄTNEJVÄZBY- ŠPECIFIKÁCIA ÚLOHY JADROVÉHO SEBAHODNOTENIA
}

\author{
B. Krenn, S. W u e r th, A. H e r g o v i c h
}

Súhrn: Dopad spätnej väzby na výkon sa ukázal ako nekonzistentný vzhl’adom na významnost' širokej škály moderujúcich premenných. Čo sa týka osobnostných čŕt - generalizovaná sebaúčinnost', self-esteem, locus of control a emočná stabilita majú vplyv na spracovávanie spätnej väzby. Výskum spätnej väzby sledoval tieto črty len samostatne, bez ohladu na ich vzájomné vzt’ahy. Zámerom štúdie bolo preskúmat’ vplyv integračného, konceptu vyššieho rádu vrátane týchto čŕt (pomenovaných ako jadrové sebahodnotenie) na účinky intervencie spätnej väzby. Respondenti $(\mathrm{N}=471)$ dostali manipulovanú pozitívnu, negatívnu alebo žiadnu spätnú väzbu (kontrolná skupina) v rámci dvoch počítačových testov. Konfirmačná faktorová analýza potvrdila koncept jadrového sebahodnotenia. Opakované merania ANOVA neodhalili vplyv jadrového sebahodnotenia na dopad spätnej väzby. S pohl’adu jednotlivých čŕt mal na silu spätnej väzby dopad len self-esteem. 